\title{
Stripping Bioethanol from Fermented Molasses in A Packed Tower
}

\author{
Andina Indah Sekararum, Andhika Sulistyani Putri, Margono* \\ Chemical Engineering Department, Faculty of Engineering, Universitas Sebelas Maret \\ Jl. Ir. Sutami 36A Surakarta, Indonesia \\ *E-mail: margono@ft.uns.ac.id (Corresponding author)
}

\begin{abstract}
The high price of bioethanol is the barrier of its implementation as renewable energy sources. Therefore, efforts to reduce its price is an important factor to drive the implementation. Stripping is a way to separate bioethanol from the broth which will be cheaper than distillation process. This research was aimed to separate bioethanol from its fermented molasses. The effect of feed flow rate, air flow rate and feed temperature were investigated. A column with inside diameter of $0.1 \mathrm{~m}$ was used and packed with $0.02 \times 0.016$ $\mathrm{m}$ PVC rashig ring at $1 \mathrm{~m}$ of bed. The broth was fed from the top side and the air stripper was flown down from the bottom side. Six millimeters of the top product was collected at steady state condition for analysis of bioethanol concentration. The best experiment was the one which had feed flow rate $1,5 \mathrm{~L} / \mathrm{min}$ and stripping air flow rate of $5,85 \mathrm{~L} / \mathrm{min}$. It resulted bioethanol content of $19.39 \%$ or equivalent to $38.5 \%$ stripped out of the broth.
\end{abstract}

Keywords: bioethanol, stripping, flow rate, column, raschig ring, broth

EQUILIBRIUM Volume 2 No.1 January 2018

Online at http:/ / equilibrium.ft.uns.ac.id 


\section{Introduction}

Public demand and consumption of fuel oil (BBM) is increasing into the recent year, while Indonesia's petroleum production continues to decline by about $5 \%$ per year [1]. A way of effort to reduce public consumption on fuel is the usage of bio-based renewable energy (biofuels) [2]. Bioethanol as one of the bio-based fuel which is proven, but its price is higher than petroleum based oil (gasoline). Thus, more studies are needed to get lower price of bioethanol through reduction of it production cost.

Ethanol production can be conducted by batch or continuous process. However, both have weakness, i.e. the resulting ethanol will mix with the substrate solution on the fermentation medium. Whereas at ethanol concentrations exceeding $2,5 \%$, the growth of fermentation microorganisms will be inhibited [3]. Ethanol products will affect the growth of yeast, such as the damage of plasma membrane, protein denaturation, and the occurrence of changes in the profile of growth temperature [4], resulting in decrease ethanol production and increase production cost. Based on these reasons, a continuous method of ethanol separation from fermentation products is required to anticipate poisoning of microorganisms in order to reduce the cost of bioethanol production

There have been many studies aimed at optimize the production of bioethanol by using separation either directly or indirectly. Some of them were azeotropic distillation [5], fermentation with trickle bed reactor [6], and extractive fermentation [7]. Stripping as one of the most commonly used separation options in industry has not received much attention in the field of fermented ethanol optimization. Therefore this research will be used stripping method as an effort to optimize bioethanol production.

In general, Stripping can be done on towers with trays and towers with packing columns. Towers with packing columns are more desirable on laboratory scale processes. The advantages of using towers with packing columns include providing a wide range of contacts between air and liquid, cheaper, more robust, and easy to install [8].

This study was aimed to determine the effect of feed flow rate, air flow rate, and feed temperature to adsorption percentage, adsorption rate, and ethanol content of fermentation product stripping on Packed Bed Stripper. The results of this study are expected to be one of literature related to the process of fermentation ethanol production optimization.

\section{Materials and Method}

\subsection{Materials and Equipment}

The material used was a fermentation broth of molasses medium. The Stripper was a packed tower which included PVC colun with inside diameter of $0.1 \mathrm{~m}$ packed with $0.02 \mathrm{~m}$ random packing pattern of plastic raschig ring and $1 \mathrm{~m}$ of bed height. The series of stripping equipment were shown in Figure 1.

\subsection{Experimental Method}

The fermentation broth and stripping air were flown at a pattern of counter current flow. The broth was fed from the top side and the stripping air was flown from the bottom side. The top product of column was caught by condensing it in an air condenser. Sampling was done at feed, top, and bottom side varied at $1,2 \mathrm{~L} / \mathrm{min} ; 1,44 \mathrm{~L} / \mathrm{min} ; 1,5 \mathrm{~L} / \mathrm{min}$. The air flow rate was varied at 3,89 L/min; $5,84 \mathrm{~L} / \mathrm{min} ; 6,81 \mathrm{~L} / \mathrm{min}$. the feed temperature was varied at $30^{\circ} \mathrm{C}$ and $40^{\circ} \mathrm{C}$. 


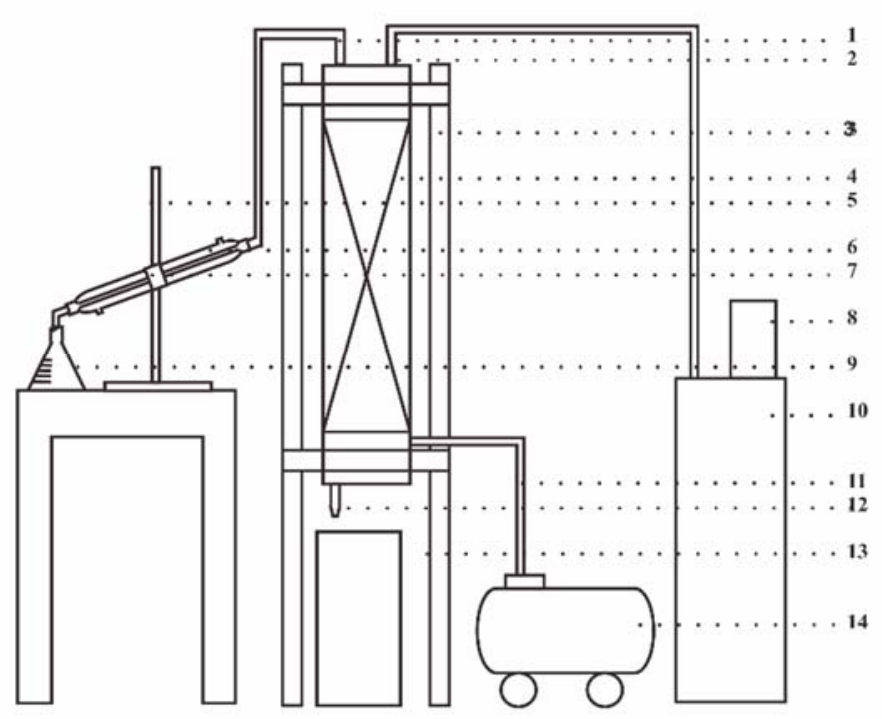

Explanation :

1. Airflow outlet

2. Liquid flow inlet

3. Stripper support

4. Packed bed column

5. Stative

6. Straight cooler

7. Clamp

8. Liquid pump

9. Erlenmeyer

10. Liquid feed tank

11. Airflow inlet

12. Liquid flow outlet

13. Product accumulator

14. Compressor

Figure 1. The Stripping Process Equipment Series

\section{Result and Discussion}

\subsection{Effect of Feed Flow Rate on Ethanol Stripping}

The effect of the feed flow rate is shown in Table 1 and Figure 2.

Table 1. The Effect of Feed Flow Rate on Product Ethanol Content (at 5,84 L/min airflow rate and feed temperature of $\left.30^{\circ} \mathrm{C}\right)$

\begin{tabular}{cccc}
\hline $\begin{array}{c}\text { Feed Flowrate* } \\
\text { (L/min) }\end{array}$ & $\begin{array}{c}\text { Feed Ethanol } \\
\text { Content (\%) }\end{array}$ & $\begin{array}{c}\text { Product } \\
\text { Ethanol } \\
\text { Content (\%) }\end{array}$ & $\begin{array}{c}\text { Stripping } \\
\text { Percentage (\%) }\end{array}$ \\
\hline 1,2 & 13,1 & 14,11 & 7,7 \\
1,44 & 14 & 15,05 & 7,5 \\
1,5 & 14 & 19,39 & 38,5 \\
\hline
\end{tabular}

Based on Table 1 it can be seen that at the constant rate of air flow and feed temperature, the higher feed flow rate resulting higher ethanol content in the product. This is caused by the increase of liquid ability to covering the surface of the packing by the increasing amount of fluid. So the area of contact between air and liquid becomes larger. Due to the larger contact area, the air is easier to adsorb ethanol in the body of liquid and mass transfer between liquid and the air occurred. As the increasing of ethanol content in the product, the stripping percentage of ethanol on the air will also increases. 


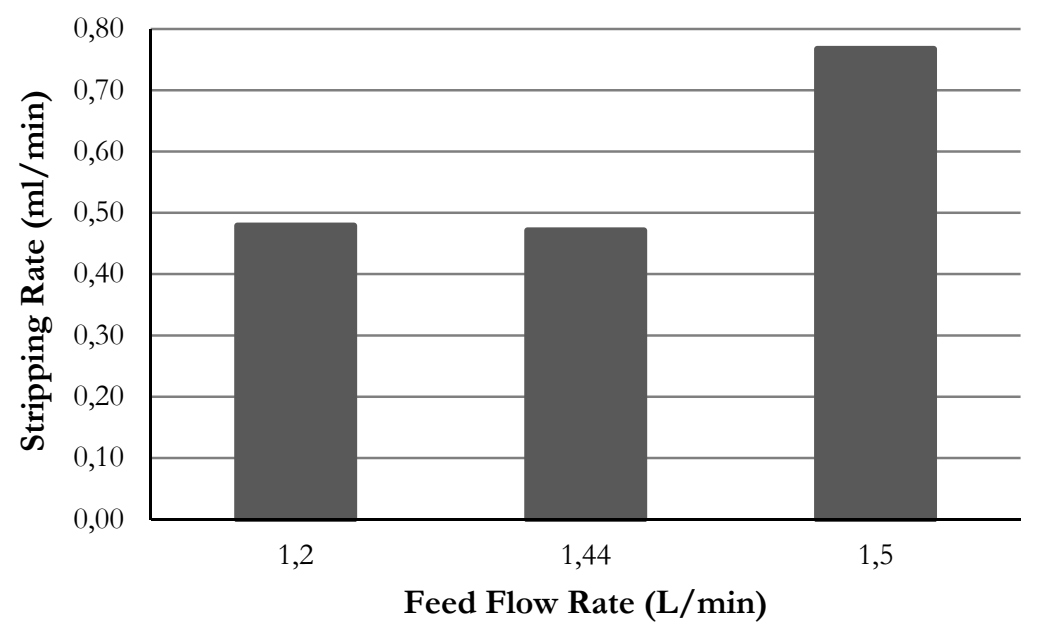

Figure 2. The effect of stripping rate to the feed flow rate

Beside of the increase in ethanol content and stripping percentage, the addition of flow rate also affects the rate of stripping. According to Fig. 2, the addition of the flow rate tends to increase the speed of the strip. This is caused by ethanol which has a higher volatility get trapped more intense by the air because of larger contact surface. So that water in the liquid did not get stripped by the air. So, the product as soon as possible reach the constant ethanol content with the increasing volume.

\subsection{Effect of Air Flow Rate on Ethanol Stripping}

The effect of the air flow rate is shown in Table 2 and Figure 3.

Table 2. The Effect of Air Flow Rate on Product Ethanol Content (at 1,38 L/min feed flow rate and feed temperature of $40^{\circ} \mathrm{C}$ )

\begin{tabular}{cccc}
\hline $\begin{array}{c}\text { Air Flowrate* } \\
\text { (L/min) }\end{array}$ & $\begin{array}{c}\text { Feed Ethanol } \\
\text { Content (\%) }\end{array}$ & $\begin{array}{c}\text { Product } \\
\text { Ethanol } \\
\text { Content (\%) }\end{array}$ & $\begin{array}{c}\text { Stripping } \\
\text { Percentage (\%) }\end{array}$ \\
\hline 3,89 & 13,1 & 15,21 & 16,107 \\
5,84 & 13,1 & 13,89 & 6,031 \\
6,81 & 13,1 & 13,89 & 6,031 \\
\hline
\end{tabular}

Based on Table 2 it can be seen that at constant flow rate and feed temperature, the higher feed flow rate lead to smaller ethanol content in the product. The percentage of ethanol adsorption in air also decreased. It happened because the greater the air flow, the easier the other substances beside ethanol in the liquid to get into the air, in this case the substance is water. At a sufficiently large flow rate, water in the liquid may be carried by airflow thus lowering the product's ethanol content.

Compared to the study conducted by Margono (2013) which stripped water-bioethanol solution using air flow rate variation $4,6 \mathrm{~L} / \mathrm{min} ; 5,9 \mathrm{~L} / \mathrm{min}$; and 7,1 L/min with $10 \%$ feed ethanol content, it can be seen that the difference is far enough. At 40 minutes of stripping with flow rate of 4,6 L/min and $10 \%$ feed concentration, the stripping percentage reached $59 \%$. While at flow rate $5,9 \mathrm{~L} / \mathrm{min}$ and $7,1 \mathrm{~L} / \mathrm{min}$ stripping percentage can reach $70 \%$ and $92 \%$ [9]. The high percentage of stripping obtained by Margono (2013) can not be separated from the least amount of impurities contained in feed fluids used in his research. On stripping using fermentation fluids, impurities such as molasses of fermentation residues, fermentation cells, and other impurities in the feed fluid may cause the difficulty of ethanol to be stripped from the fluid body. So the adsorption rate of stripping with fermented liquid feed gives a fairly small number compared to the water-bioethanol feed. 


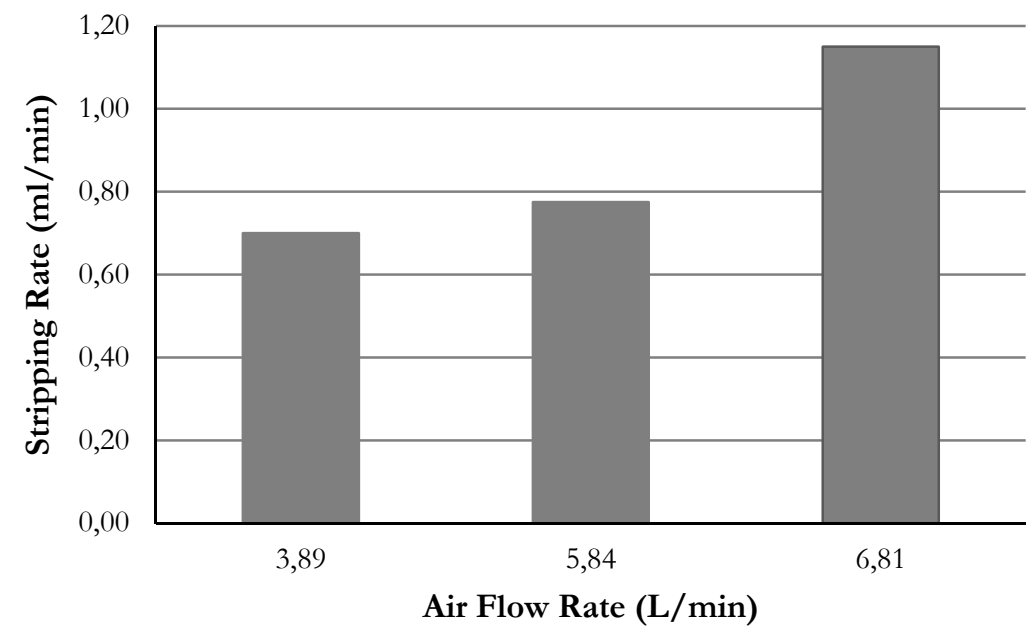

Figure 3. The effect of stripping rate to the air flow rate

Moreover, the addition of air flow rate also influences the stripping rate. According to Fig. 3, the addition of the air flow rate shows the same tendency as the addition of the feed flow rate. However, the rate of stripping in the variation of air flow rate was not in line with the increase in ethanol content in the product. The reason is that the amount of air flow rate makes ethanol and water easier to escape from the body of the liquid. So the time required for product to reach a constant ethanol content were faster. On the other hand, the amount of water entrapped by the air made product seems have increasing in volume, whereas in fact in most of the product collected was water instead of ethanol.

\subsection{Effect of Feed Temperature on Ethanol Stripping}

The effect of the feed temperature is shown in Table 3 and Figure 4.

Table 3. The Effect of Feed Temperature on Product Ethanol Content (at 1,44 L/min feed flow rate and $5,84 \mathrm{~L} / \mathrm{min}$ airflow rate)

\begin{tabular}{cccc}
\hline $\begin{array}{c}\text { Feed } \\
\text { Temperature* } \\
\left({ }^{\mathbf{0}} \mathbf{C}\right)\end{array}$ & $\begin{array}{c}\text { Feed Ethanol } \\
\text { Content (\%) }\end{array}$ & $\begin{array}{c}\text { Product } \\
\text { Ethanol } \\
\text { Content (\%) }\end{array}$ & $\begin{array}{c}\text { Stripping } \\
\text { Percentage (\%) }\end{array}$ \\
\hline 30 & 14 & 15,05 & 7,5 \\
40 & 14 & 15,21 & 8,64 \\
\hline
\end{tabular}

Based on Table 3 it can be seen that at the constant rate of air flow and feed flow, higher feed temperature render to the higher ethanol content in the product and also the percentage of stripping. Lower boiling point of ethanol than any other substances in the feed liquid caused feed heating lead it to its boiling point, so ethanol can easily escape from the feed liquid. In the other hand, the surface tension of the liquid will decrease with increasing temperature, so that ethanol will more easily come out of the bulk.

According to Fig. 4, the addition of feed temperature tends to increase the stripping rate. Such as the rise in rate of stripping on variations in feed and air flow rates, the increased rate of stripping is caused by the ease of ethanol being absorbed by air due to the decrease of surface tension. On the other hand, the air flow rate is not large enough to strip much water in the liquid. So the volume of ethanol-rich product increases with the speed of time the product reaches a constant level. 




Figure 4. The effect of stripping rate to the feed temperature

\section{Conclusions}

Based on this research can be concluded as follows:

a. The greater feed flow rate leads to the increasing area of contact between ethanol-air, thus increasing the ethanol content and stripping percentage in the product.

b. The greater the rate of air flow causes the more easily the substances other than ethanol get absorbed by the air, thus lowering the ethanol content and stripping percentage in the product.

c. The greater the feed temperature causes the smaller the surface tension of the liquid, thereby increasing the ethanol content and stripping percentage on the product.

d. The greater the feed flow rate, the air flow rate, and also the feed temperature causes the greater rate of stripping

e. Stripping percentage of water-bioethanol feed is more higher than fermentation solution feed on separation method used stripper.

\section{References}

[1] Badan Pengkajian dan Penerapan Teknologi, "Outlook Energi Indonesia 2016", Pusat Teknologi Pengembangan Sumber Daya Energi (PTSE), Jakarta, 2015

[2] Republik Indonesia, "Peraturan Presiden No. 5 Tahun 2006 tentang Kebijakan Energi Nasional", Lembaran Negara RI Tahun 2006, Sekertariat Negara, Jakarta, 2006

[3] Azizah, N., et al., "Pengaruh Lama Fermentasi terhadap Kadar Alkohol, pH, dan Produksi Gas pada Proses Fermentasi Bioetanol dari Whey dengan Substitusi Kulit Nanas," Jurnal Aplikasi Teknologi Pangan, vol. 1, no. 2, 2012.

[4] Galeote, V.A., et al, "Global Gene Expression during Short-Term Ethanol Stress in Saccharomyces Cerevisiae," Biotechnology Letters, no. 498, pp. 98-103, 2001.

[5] Bisowarno, B.H., et al, "Simulasi Proses Dehidrasi Etanol dengan Kolom Distilasi Azeotrop Menggunakan Isooktan," Prosiding Seminar Nasional Teknik Kimia Kejuangan, 2010.

[6] Margono, "Uji Kinerja pada Proses Produksi Etanol Melalui Kombinasi Proses Fermentasi dan Stripping," Ekuilibrium, vol. 11, no. 2, 2012.

[7] Rosyadi, F.A., et al, "Optimasi Proses Produksi Etanol dari Molases Menggunkan Teknik FermentasiEkstraktif," Jurnal Teknik Pomits, vol. 3, no. 2, 2013.

[8] Treybal, R.E., "Distilation," in Mass Transfer Operation, 3rd ed. New York,: Mc Graw Hill Company, 1981.

[9] Margono, Budiono, "Stripping Larutan Bioetanol Menggunakan Udara," Ekuilibrium, vol. 12, no. 2, pp. 59-61, 2013. 